\title{
Attitude of Spouse towards Family Planning: A Study among Married Men and Women of a Rural Community in West Godavari District, Andhra Pradesh
}

\author{
G.R. Varma and A. Rohini \\ Department of Social Work, School of Distance Education, Andhra University, \\ Visakhapatnam 530 003, Andhra Pradesh, India \\ Telephone: +891 2754966 (office), 2539078 (home) \\ E-mail: anamrohini@gmail.com
}

KEYWORDS Family Planning. Attitude. Rural. Andhra Pradesh

\begin{abstract}
The fertility data indicate that there is a need to change to scenario of contraception use in India. The present paper reports the attitude of spouse on the practice of family planning in a rural population from West Godavari district, Andhra Pradesh, India. The information was collected through in-depth interviews with structured questionnaire. A considerable proportion of people reported that their spouse encouraged to adopt family planning. And very few people reported that their spouse opposed and discouraged the use of family planning methods. There was no trend of association with attitude of spouse with age and caste of respondents. But literacy and occupation had influence. In addition, majority of respondents opined that female sterilising (tubectomy) was a better permanent sterilization. No apparent association was seen between this attitude and characteristics of the respondent. Also, more than two-thirds of men and less than half of women reported that they advised others to adopt family planning. Family panning through contraception tries to achieve the principal objective to have only the desired number of children. Hence, the study warrants improving the attitude of the people, in favour of family planning and special strategies are to be planned to improve the involvement of men.
\end{abstract}

\section{INTRODUCTION}

Currently, India is the second most populous country in the world, contributing about $20 \%$ of births worldwide (World Health Organization, 2006). Also, it continued to have one of the most rapidly growing populations in the world. However, third National Family Health Survey (NFHS-3) reported that fertility continues to decline in India. The current total fertility rate (TFR) of 2.7 is down slightly from 2.9 children per woman at the time of second National Family Health Survey (NFHS-2), but is still well above the replacement level of just over two children per woman (International Institute for Population Sciences and ORC Macro, 2000, 2007). The National Family Welfare Programme in India has traditional sought to promote responsible and planned parenthood through voluntary and free choice of contraceptive methods best suited to

Address for correspondence:

Dr. A. Rohini

Associate Professor of Social Work

School of Distance Education, Andhra University,

Visakhapatnam 530 003, Andhra Pradesh, India

Telephone: +8912754966 (office), 2539078 (home)

Email: anamrohini@gmail.com individual acceptors (Ministry of Health and Family Welfare, 1998). India launched the National Family Welfare Programme in 1951 with the objective of reducing the birth rate to the extent necessary to stabilize the population, consistent with the requirements of the national economy. Since its inception, the programme has experienced significant growth in terms of financial investment, service delivery points, type of services, and the range of contraceptive methods offered. Since October 1997, the services and interventions under the Family Welfare Programme and the Child Survival and Safe Motherhood Programme have been integrated with the Reproductive and Child Health Programme. In the National Population Policy, 2000, the Government of India set as its immediate objective the task of addressing unmet need for contraception to achieve the mediumrange objective of bringing the total fertility rate down to replacement level by 2010. One of the socio-demographic goals identified for this purpose is to achieve universal access to information/counseling and services for fertility regulation and contraception with a wide range of choices (Ministry of Health and Family Welfare, 2000). In India as a whole, current 
contraceptive rate of currently married women is $56 \%$. Female sterilization, with prevalence of $37 \%$, accounted for $71 \%$ of all contraceptive use in India (International Institute for Population Sciences and ORC Macro, 2007). Still there is need to change to scenario of contraception use in India. In this context, the present paper reports the attitude of spouse on practice of family planning in a rural population of two mandals of West Godavari district, Andhra Pradesh, India.

\section{METHODOLOGY}

The information for the present study was obtained from 214 households, selected from three villages in Palakol and Palakoderu mandals (development blocks) of West Godavari district, Andhra Pradesh. The study area possessed all types of caste communities belonged to Hindu and Christian religions. The economy of the area was agricultural based through some people depended on service and business. The information pertaining to demographic and socioeconomic characteristics of households, and attitude of spouse regarding family planning acceptance, was collected through in-depth interviews with structured questionnaire. The data were entered into a personal computer and analysis was done through SPSS v.10 (SPSS inc. Chicago, IL, USA). The respondents were categorised based on their age, caste, occupation, education, income and age at marriage. Based on the caste, the respondents were categorized in to two categories, i.e. scheduled caste (SC) and non SC.

\section{RESULTS AND DISCUSSION}

The data on attitude of spouse about family planning by the characteristics of respondents are summarized and results are shown in Table 1. A considerable proportion of men $(57.5 \%)$ and women $(42.5 \%)$ reported that their spouse encouraged to adopt family planning. And very

Table 1: Distribution of respondents based on their spouse's attitude regarding family planning by socio-demographic characteristics

\begin{tabular}{|c|c|c|c|c|c|c|}
\hline & \multicolumn{3}{|c|}{ Men } & \multicolumn{3}{|c|}{ Women } \\
\hline & Encourage & Neutral & Oppose & Encourage & Neutral & Oppose \\
\hline \multicolumn{7}{|l|}{ Age Group } \\
\hline$\leq 30(\mathrm{M}=18, \mathrm{~F}=10)$ & 6.3 & 2.9 & 1.1 & 15.0 & 7.5 & 2.5 \\
\hline $31-40(\mathrm{M}=62, \mathrm{~F}=9)$ & 22.4 & 12.0 & 1.1 & 15.0 & 7.5 & - \\
\hline $41-50(\mathrm{M}=60, \mathrm{~F}=13)$ & 20.1 & 14.4 & - & 5.0 & 25.0 & 2.5 \\
\hline$\geq 51(\mathrm{M}=34, \mathrm{~F}=8)$ & 8.6 & 9.8 & 1.1 & 7.5 & 12.5 & - \\
\hline \multicolumn{7}{|l|}{ Caste } \\
\hline $\mathrm{SC}(\mathrm{M}=154, \mathrm{~F}=39)$ & 51.1 & 34.5 & 2.9 & 42.5 & 50.0 & 5.0 \\
\hline Non $S C(M=20, F=1)$ & 6.3 & 4.6 & 0.6 & - & 2.5 & - \\
\hline \multicolumn{7}{|l|}{ Occupation } \\
\hline Agriculture labour $(\mathrm{M}=112, \mathrm{~F}=32)$ & 35.6 & 25.9 & 2.9 & 32.5 & 45.0 & 2.5 \\
\hline Small farmer $(M=31, F=0)$ & 12.0 & 5.2 & 0.6 & - & - & - \\
\hline Employee $(\mathrm{M}=24, \mathrm{~F}=2)$ & 7.5 & 6.3 & - & 2.5 & 2.5 & - \\
\hline House wife $(\mathrm{M}=0, \mathrm{~F}=6)$ & - & - & - & 7.5 & 5.0 & 2.5 \\
\hline Others $(\mathrm{M}=7, \mathrm{~F}=0)$ & 2.3 & 1.7 & - & - & - & - \\
\hline \multicolumn{7}{|l|}{ Education } \\
\hline Illiterate $(M=52, F=16)$ & 16.7 & 12.6 & 0.6 & 10.0 & 12.5 & 2.5 \\
\hline Primary education $(\mathrm{M}=50, \mathrm{~F}=11)$ & 15.5 & 11.5 & 1.7 & 15.0 & 27.5 & - \\
\hline Secondary education. \& more $(\mathrm{M}=72, \mathrm{~F}=13)$ & 25.3 & 14.9 & 1.1 & 17.5 & 12.5 & 2.5 \\
\hline \multicolumn{7}{|l|}{ Annual Income } \\
\hline$\leq 8,000(\mathrm{M}=84, \mathrm{~F}=24)$ & 23.6 & 21.8 & 2.9 & 27.5 & 30.0 & 2.5 \\
\hline $8,001-10,000(\mathrm{M}=32, \mathrm{~F}=6)$ & 12.1 & 5.7 & 0.6 & 2.5 & 10.0 & 2.5 \\
\hline $10,001-20,000(\mathrm{M}=39, \mathrm{~F}=5)$ & 14.9 & 7.5 & - & 5.0 & 7.5 & - \\
\hline$\geq 20,001(\mathrm{M}=19, \mathrm{~F}=5)$ & 6.9 & 4.0 & 7.5 & 5.0 & - & - \\
\hline \multicolumn{7}{|l|}{ Age at Marriage } \\
\hline$\leq 20(\mathrm{M}=92, \mathrm{~F}=37)$ & 27.6 & 23.6 & 1.7 & 37.5 & 50.0 & 5.0 \\
\hline $21-25(\mathrm{M}=72, \mathrm{~F}=3)$ & 25.9 & 14.4 & 1.1 & 5.0 & 2.5 & - \\
\hline$\geq 26(\mathrm{M}=10, \mathrm{~F}=0)$ & 4.0 & 1.1 & 0.6 & - & - & - \\
\hline Total & 57.5 & 39.1 & 3.4 & 42.5 & 52.5 & 5.0 \\
\hline
\end{tabular}

All figures are percentages to corresponding sample.

$\mathrm{M}=$ male, $\mathrm{F}=$ female 
few people (3.4\% of men and 5\% of women) reported that their spouse opposed and discouraged the use of family planning methods. However, a considerable proportion of men $(39.1 \%)$ and women $(52.5 \%)$ reported the neutral attitude of their spouses. The multiple classification analysis based on various independent variables indicated that there was no trend of association with attitude of spouse with age structure and caste. The respondents from agricultural labourers possessed relatively lesser proportion of spouse with encouraging attitude towards family planning than other categories of occupation. Similarly, illiterates also exhibited a similar trend compared to literates. First National Family Health Survey comprised information on approval and disapproval of family planning among couples, distinguishing attitudes of wives and husbands. In India, both the wife and the husband disapprove the family planning for $58 \%$ of couples. The proportion who approved of family planning and whose husbands also approved in larger was among women who live in urban areas than in rural areas; larger among more educated women than among the less educated; and it is larger among SC (International Institute for Population Sciences, 1995).

Table 2 reports the attitude of male and female respondents on attitude on method of permanent sterilization. The respondents were asked to respond which one is a better permanent sterilization, male sterilization (vasectomy) or female sterilization (tubectomy). Majority male and female respondents (85\%) opined that female sterilization (tubectomy) is a better permanent sterilization. And the remaining $15 \%$ respondents felt that permanent sterilization of husband (vasectomy) is the best. No apparent association was seen between this attitude and age of the respondent. Higher number of SC respondents and respondents from agricultural labourers have their opinion that wife sterilization is the better way. But no variations were recorded with respect to income. Age at marriage and age at

Table 2: Distribution of respondents based on the attitude regarding better permanent sterilization by socio-demographic characteristics

\begin{tabular}{|c|c|c|c|c|}
\hline & \multicolumn{2}{|c|}{ Men } & \multicolumn{2}{|c|}{ Women } \\
\hline & $\begin{array}{c}\text { Female } \\
\text { sterilization }\end{array}$ & $\begin{array}{c}\text { Male } \\
\text { sterilization }\end{array}$ & $\begin{array}{c}\text { Female } \\
\text { sterilization }\end{array}$ & $\begin{array}{c}\text { Male } \\
\text { sterilization }\end{array}$ \\
\hline \multicolumn{5}{|l|}{ Age Group } \\
\hline$\leq 30(\mathrm{M}=18, \mathrm{~F}=10)$ & 9.8 & 0.6 & 22.5 & 2.5 \\
\hline $31-40(\mathrm{M}=62, \mathrm{~F}=9)$ & 29.9 & 5.7 & 17.5 & 5.0 \\
\hline $41-50(\mathrm{M}=60, \mathrm{~F}=13)$ & 29.9 & 4.6 & 27.5 & 5.0 \\
\hline$\geq 51(\mathrm{M}=34, \mathrm{~F}=8)$ & 15.5 & 4.0 & 17.5 & 2.5 \\
\hline \multicolumn{5}{|l|}{ Caste } \\
\hline $\mathrm{SC}(\mathrm{M}=154, \mathrm{~F}=39)$ & 77.0 & 11.5 & 82.5 & 15.0 \\
\hline Non $S C(M=20, F=1)$ & 8.0 & 3.4 & 2.5 & - \\
\hline \multicolumn{5}{|l|}{ Occupation } \\
\hline Agriculture labour $(\mathrm{M}=112, \mathrm{~F}=32)$ & 58.6 & 5.7 & 67.5 & 12.5 \\
\hline Small farmer $(M=31, F=0)$ & 14.4 & 3.4 & - & - \\
\hline Employee $(M=24, F=2)$ & 9.8 & 4.0 & 5.0 & - \\
\hline House wife $(M=0, F=6)$ & - & - & 12.5 & 2.5 \\
\hline Others $(\mathrm{M}=7, \mathrm{~F}=0)$ & 2.3 & 1.7 & - & - \\
\hline \multicolumn{5}{|l|}{ Education } \\
\hline Illiterate $(M=52, F=16)$ & 28.2 & 1.7 & 35.0 & 5.0 \\
\hline Primary education $(\mathrm{M}=50, \mathrm{~F}=11)$ & 23.0 & 5.7 & 25.0 & 2.5 \\
\hline Secondary education. \& more $(M=72, F=13)$ & 33.9 & 7.5 & 25.0 & 7.5 \\
\hline \multicolumn{5}{|l|}{ Annual Income } \\
\hline$\leq 8,000(\mathrm{M}=84, \mathrm{~F}=24)$ & 43.7 & 4.6 & 52.5 & 7.5 \\
\hline $8,001-10,000(\mathrm{M}=32, \mathrm{~F}=6)$ & 15.5 & 2.9 & 12.5 & 2.5 \\
\hline $10,001-20,000(\mathrm{M}=39, \mathrm{~F}=5)$ & 19.0 & 3.4 & 10.0 & 2.5 \\
\hline$\geq 20,001 \quad(\mathrm{M}=19, \mathrm{~F}=5)$ & 6.9 & 4.0 & 10.0 & 2.5 \\
\hline \multicolumn{5}{|l|}{ Age at Marriage } \\
\hline$\leq 20(\mathrm{M}=92, \mathrm{~F}=37)$ & 47.7 & 5.2 & 80.0 & 12.5 \\
\hline $21-25 \quad(\mathrm{M}=72, \mathrm{~F}=3)$ & 33.3 & 8.0 & 5.0 & 2.5 \\
\hline$\geq 26(\mathrm{M}=10, \mathrm{~F}=0)$ & 4.0 & 1.7 & & \\
\hline Total & 85.1 & 14.9 & 85.0 & 15.0 \\
\hline
\end{tabular}

All figures are percentages to corresponding sample. $\mathrm{M}=$ male, $\mathrm{F}=$ female 
first child have also impact on this attitude. The respondents with lower values of these variables have the attitude that tubectomy is better for permanent sterilization.

Table 3 presents distribution of respondents based on the attitude of giving advice to others in favour of family planning by socio-demographic characteristics. Out of all respondents, $68.4 \%$ and $45 \%$ women reported that they advised others to adopt family planning. These results are not welcoming since one-third of the men and more than half of women were not in favour of family planning, and do not advice others. There was a considerable degree of variation in this aspect. The data revealed that the proportion of respondents who were in favour of family planning was more among lower age group people. This proportion was higher among non-SC respondents than SC respondents. Regarding occupational division of respondents, more number of agricultural labourers were not giving advice to others in favour of family planning. Similarly, there was an association between education and this attitude. Among illiterate respondents only $52 \%$ were in favour of family planning where as among literates this number was more than $75 \%$. Among respondents with income of less than Rs. 6000 possessed $70 \%$ of respondents who were in favour of family planning, while $87.7 \%$ of respondents with income above Rs. 6000 were favouring family planning. Relatively higher proportion of respondents exhibited positive attitude towards family planning and advised others to adopt family planning.

Family panning through contraception tries to achieve the principal objective to have only the desired number of children. It is known that particularly men's attitudes about contraception may influence their partner's attitudes and eventual adoption of a contraceptive method (International Institute for Population Sciences and ORC Macro, 2007). In the present study, only about half of the men have positive attitude and they seemed to encourage their wives to adopt

Table 3: Distribution of respondents based on their attitude to give advice to others in favour of family planning by socio-demographic characteristics

\begin{tabular}{|c|c|c|c|c|}
\hline & \multicolumn{2}{|c|}{ Men } & \multicolumn{2}{|c|}{ Women } \\
\hline & Yes & No & Yes & $\mathrm{No}$ \\
\hline \multicolumn{5}{|l|}{ Age Group } \\
\hline$\leq 30(\mathrm{M}=18, \mathrm{~F}=10)$ & 8.0 & 4.0 & 15.0 & 17.5 \\
\hline $31-40(\mathrm{M}=62, \mathrm{~F}=9)$ & 26.4 & 9.2 & 10.0 & 12.5 \\
\hline $41-50(\mathrm{M}=60, \mathrm{~F}=13)$ & 25.9 & 8.6 & 15.0 & 17.5 \\
\hline$\geq 51(\mathrm{M}=34, \mathrm{~F}=8)$ & 8.6 & 10.9 & 7.5 & 12.5 \\
\hline \multicolumn{5}{|l|}{ Caste } \\
\hline $\mathrm{SC}(\mathrm{M}=154, \mathrm{~F}=39)$ & 59.8 & 28.7 & 45.0 & 52.5 \\
\hline Non $\mathrm{SC}(\mathrm{M}=20, \mathrm{~F}=1)$ & 8.6 & 2.9 & - & 2.5 \\
\hline \multicolumn{5}{|l|}{ Occupation } \\
\hline Agriculture labour $(\mathrm{M}=112, \mathrm{~F}=32)$ & 41.4 & 23.0 & 37.5 & 42.5 \\
\hline Small farmer $(\mathrm{M}=31, \mathrm{~F}=0)$ & 13.8 & 4.0 & - & - \\
\hline Employee $(\mathrm{M}=24, \mathrm{~F}=2)$ & 10.3 & 3.4 & - & 5.0 \\
\hline House wife $(\mathrm{M}=0, \mathrm{~F}=6)$ & - & - & 7.5 & 7.5 \\
\hline Others $(\mathrm{M}=7, \mathrm{~F}=0)$ & 2.9 & 1.1 & - & - \\
\hline \multicolumn{5}{|l|}{ Education } \\
\hline Illiterate $(\mathrm{M}=52, \mathrm{~F}=16)$ & 15.5 & 14.4 & 17.5 & 22.5 \\
\hline Primary education $(\mathrm{M}=50, \mathrm{~F}=11)$ & 20.7 & 8.0 & 12.5 & 15.0 \\
\hline Secondary education. \& more $(\mathrm{M}=72, \mathrm{~F}=13)$ & 32.2 & 8.2 & 15.0 & 17.5 \\
\hline \multicolumn{5}{|l|}{ Annual Income } \\
\hline$\leq 8,000(\mathrm{M}=84, \mathrm{~F}=24)$ & 30.5 & 17.8 & 32.5 & 27.5 \\
\hline $8,001-10,000(\mathrm{M}=32, \mathrm{~F}=6)$ & 19.5 & 12.6 & 15.0 & 12.5 \\
\hline $10,001-20,000(M=39, F=5)$ & 14.9 & 7.5 & 2.5 & 10.0 \\
\hline$\geq 20,001 \quad(M=19, F=5)$ & 8.6 & 2.3 & 7.5 & 5.0 \\
\hline \multicolumn{5}{|l|}{ Age at Marriage } \\
\hline$\leq 20(\mathrm{M}=92, \mathrm{~F}=37)$ & 35.6 & 17.8 & 37.5 & 55.0 \\
\hline $21-25(\mathrm{M}=72, \mathrm{~F}=3)$ & 28.7 & 12.6 & 7.5 & - \\
\hline$\geq 26(\mathrm{M}=10, \mathrm{~F}=0)$ & 4.6 & 1.1 & - & - \\
\hline Total & 68.4 & 31.6 & 45.0 & 55.0 \\
\hline
\end{tabular}

All figures are percentages to corresponding sample. 
the family planning. Also several, sociodemographic characters were also influenced the attitude of the people. In terms of attitude as well in practice, tubectomy was the popular method of permanent sterilization and remained as a dominant method of all family planning methods. The study warrants to improve the attitude of the people, in favour of family planning and special strategies are to be planned to improve the involvement of men. Research on the attitude and practice of men regarding fertility regulation and the factors inhibiting their role and participation in reproductive health could help improve and modify the situation (Santhya, 2003).

\section{REFERENCES}

International Institute for Population Sciences: National Family Health Survey (MCH and Family Planning), India 1992-93. International Institute for Population Sciences, Bombay (1995).
International Institute for Population Sciences and ORC Macro: National Family Health Survey (NFHS-2), 1998-99. International Institute for Population Sciences, Bombay (2000).

International Institute for Population Sciences and Macro International: National Family Health Survey (NFHS-3), 2005-06: India: Volume I. International Institute for Population Sciences, Mumbai (2007). Ministry of Health and Family Welfare. 1998. Family Welfare Programme in India, Year Book, 19961997. Department of Family Welfare, Ministry of Health and Family Welfare, New Delhi (1998).

Ministry of Health and Family Welfare: National Population Policy, 2000. New Delhi: Department of Family Welfare, Ministry of Health and Family Welfare.

Santhya. K.G.: Changing Family Planning Scenario in India: an Overview of Recent Evidence. Regional Working Papers No. 17. Population Council, New Delhi (2003)

World Health Organization: India and Family Welfare Planning, an Overview. South-East Asia Regional Office, World Health Organization, New Delhi (2006). 